\title{
VISOKO OBRAZOVANJE STUDENATA S INVALIDITETOM U HRVATSKOJ
}

Pregledni rad

Primljeno: rujan, 2014.

Prihvaćeno: studeni, 2014.

UDK 378-056.26-057.87

DOI 10.3935/jsr.v21i2.40

\section{SAŽETAK}

Načela osiguravanja jednakog pristupa i prilika visokom obrazovanju danas su dio globalne inicijative za poticanje prava na obrazovanje za sve, te su posljednjih desetljeća sve zastupljenija i u hrvatskom prostoru javnih politika obrazovanja.

U radu je dan prikaz postojećih javnih politika visokog obrazovanja studenata s invaliditetom kao podzastupljene skupine u visokom obrazovanju u zemljama Europske unije i Republici Hrvatskoj. Poseban naglasak u radu stavljen je na prikaz i razradu postojeće zakonske regulative te analizu provedenih mjera visokog obrazovanja za studente s invaliditetom. Rad ujedno sadrži $i$ procjenu kvalitete visokog obrazovanja studenata s invaliditetom u Republici Hrvatskoj.

Analizom sadržaja dostupnih dokumenata, te politika i mjera usmjerenih povećanju sudjelovanja studenata s invaliditetom u visokom obrazovanju, u radu je ponuđen pregled postojećeg stanja, te se utvrđuju preduvjeti njegovih promjena. Ciljajući nužnosti sustavnog rada na podizanju kvalitete visokog obrazovanja studenata s invaliditetom u Hrvatskoj, u zaključku su ujedno definirane preporuke za unapređenje sadašnjeg sustava.

\footnotetext{
1 Mr. sc. Sandra Bošković, profesorica edukacijske rehabilitacije, e-mail: sandra.boskovic@medri.uniri.hr

${ }^{2}$ Doc.dr. sc. Iva Rinčić, profesor sociologije, e-mail: rincic@medri.uniri.hr
}

Ključne riječi:

visoko obrazovanje za sve, inkluzivni pristup, studiranje s invaliditetom, zakonski okvir visokog obrazovanja, Republika Hrvatska. 


\section{UVOD}

Problem socijalne isključenosti osoba s invaliditetom otprije je poznat stručnoj i znanstvenoj javnosti kao jedan od vodećih socijalnih problema suvremenog svijeta u kojem osobe s invaliditetom još uvijek predstavljaju marginaliziranu društvenu skupinu.

Suvremeni pristup poboljšanju kvalitete življenja osoba s invaliditetom temeljen na filozofiji inkluzije polazi od pretpostavke da je položaj osoba s invaliditetom, kao i njihova diskriminacija, društveno uvjetovan. Inkluzivni pristup polazi od nužnosti omogućavanja osobama s invaliditetom kontrole vlastitoga života te podrazumijeva čitav niz promjena. Spomenuto vodi društvu inkluzije, čija realizacija treba zaživjeti, kako na razini individualne svijesti, tako i na razini kolektiva, poprimajući formu novog društvenog koncepta (Rieser, 1994.).

$U$ duhu inkluzivnog pristupa potrebno je ukloniti postojeće socijalne zapreke - stavove, društvena i pravna ograničenja, konačno i fizičke barijere u okolini, koje i danas predstavljaju socijalni konstrukt sa značajnom utjecajem na kvalitetu života osoba s invaliditetom.

Inkluzivni pristup omogućio je kreiranje javnih politika iz kojih su proizašli ključni međunarodni dokumenti koji su otvorili put poboljšanju kvalitete življenja osoba $s$ invaliditetom. Posebno važan segment dokumenata ${ }^{3}$ je važnost obrazovanja kao značajnog elementa poboljšanja kvalitete života svakog pojedinca. Konvencija o pravima osoba s invaliditetom ${ }^{4} \mathrm{u}$ dijelu koji se odnosi na obrazovanje, obvezuje zemlje potpisnice na osiguravanje prava osoba $s$ invaliditetom na obrazovanje, bez diskriminacije i na osnovi jednakih mogućnosti. Promatranje problematike osoba s invaliditetom u terminima ljudskih prava bila ja novina ne samo iz perspektive osoba s invaliditetom, nego i za društvo u cjelini, promovirajući načelo inkluzivnog društva. Inkluzivno društvo temeljeno je na socijalnom modelu pristupa osobama s invaliditetom, čime se načelno ostvaruju preduvjeti pune ravnopravnosti i uključenosti svakog pojedinca u zajednicu i doprinos njegovom razvoju. Kao model, inkluziju je stoga nužno sagledavati iz različitih aspekata društvenog djelovanja, od obrazovanja, do sustavnog društvenog shvaćanja oso-

\footnotetext{
${ }^{3}$ Konvencija o zaštiti ljudskih prava i temeljnih sloboda sa protokolima (NN, 18/97, 6/99, 14/02, 13/03, 9/05, 1/06, 2/10), Konvencija o pravima djeteta (1989.), World Declaration on Education for All and Framework for Action to Meet Basic Learning Needs (Svjetska deklaracija o obrazovanju za sve i okvir akcija za postizanje temeljnih potreba učenja) (1990.), Standard Rules for Equalisation of Opportunities for Persons with Disability (Standardna pravila za izjednačavanje mogućnosti osoba s invaliditetom) (1993.), The Salamanca Statement and Framework on Special Needs Education (Izjava o okvir iz Salamanke o posebnim potrebama edukacije) (1994.), World Education Forum - The Dakar Framework for Action (Svjetski forum obrazovanja - Okvir za djelovanje iz Dakra) (2000.).

${ }^{4}$ Zakon o potvrđivanju Konvencije o pravima osoba s invaliditetom i Fakultativnog protokola uz Konvenciju o pravima osoba sa invaliditetom (2007.) (NN, 6/07, 3/08, 5/09).
} 
ba s invaliditetom, te poimanja individualnih vrednosti (Clark i sur., 2000.), pri čemu upravo obrazovanju pripada značajna uloga u realizaciji socijalno-kulturološke dimenzije društva.

Osiguravanje jednakog pristupa obrazovanju na svim razinama u skladu s individualnim potrebama osoba s invaliditetom te podrškom unutar općeg obrazovnog sustava s ciljem akademskog, ali i socijalnog razvoja osoba s invaliditetom, zastupljeno je i u već spomenutoj Konvenciji o pravima osoba s invaliditetom (2007.). Naime, kreiranjem inkluzivnog obrazovanja omogućava se ne samo razvoj socijalne kompetencije svih uključenih u obrazovni proces, već se postiže aktivnije uključivanje osoba s invaliditetom u obrazovni sustav. Na taj se način osiguravaju preduvjeti razvoja socijalne kompetencije, odnosno razvoja socijalnih, emocionalnih i intelektualnih vještina i ponašanja koje su preduvjet akademskom i socijalnom razvoju osobe sukladno njegovim sposobnostima (Milašin, Vranić i Buljubašić Kuzmanović, 2009.).

Pojmovi poput prava na obrazovanje, inkluzivno obrazovanje, socijalna dimenzija obrazovanja, podzastupljene skupine u visokom obrazovanju, načelo jednakih prilika u obrazovanju ili obrazovanja za sve, prilagodba akademskog okruženja neizostavne su teme u međunarodnim raspravama o obrazovanju, ali i u raspravama iz područja ljudskih prava, socijalnog uključivanja i gospodarskog razvoja (Pavić i Vukelić, 2009.).

Svi spomenuti pojmovi upućuju na nužnost izjednačavanje uvjeta obrazovanja koji su povezani s obrazovnim postignućima kako bi svi pojedinci imali mogućnost realiziranja svojih sposobnosti, tj. kako bi obrazovna postignuća svakog pojedinca bila što više povezana s njegovim sposobnostima i uloženim trudom (Pavić i Vukelić, 2009.).

Isticanjem drugačijeg sagledavanja uloge obrazovanja s naglaskom na inkluzivni pristup, mladi s invaliditetom postaju središte interesa stvaranja preduvjeta jednakih prilika u obrazovanju jer predstavljaju jednu od najranjivijih društvenih skupina suočenu s ozbiljnim preprekama na svim razinama obrazovanja, a posebno u visokom obrazovanju ${ }^{5}$.

\section{VISOKO OBRAZOVANJE ZA SVE}

Načela osiguravanja jednakog pristupa i jednakih prilika u visokom obrazovanju danas su dio globalne inicijativa za poticanje prava na obrazovanje za sve. $U$ usporedbi s uključivanjem djece s teškoćama u razvoju u osnovno i srednjoškolsko obrazovanje koje se već duže vrijeme provodi i temelji se na principima inkluziv-

\footnotetext{
${ }^{5}$ Policy Guidelines on Inclusion in Education (Smjernice politika za inkluziju u edukaciji) (2009.).
} 
nog obrazovanja, inkluzivno obrazovanje u visokom školstvu u zadnjem desetljeću penje se na popisu prioriteta politika visokog obrazovanja (Farnell i Kovač, 2010.).

Organizacija Ujedinjenih naroda za obrazovanje, znanost i kulturu (UNESCO) »Obrazovanje za sve« djeluje na tragu ciljeva i mjera istaknutih u okviru »Milenijskih ciljeva razvoja « Ujedinjenih naroda, a spomenuto su preuzele i članice Vijeća Europe 2003. godine. Navedenim se dokumentima također nedvosmisleno definira potreba osiguravanja svih preduvjeta pristupa visokom obrazovanju još uvijek podzastupljenim skupinama, među kojima su i osobe s invaliditetom (Farnell i Kovač, 2010.).

U okviru Strategije Europe 2020. za pametan, održiv i uključiv rast, obrazovanje (a posebno visoko obrazovanje) ima ključnu ulogu u ostvarivanju postavljenih strateških ciljeva. Jedan od najznačajnijih ciljeva je povećanje pristupa visokom obrazovanju kroz omogućavanje dostupnosti visokog obrazovanja što većem broju građana, posebno onih skupina koje su još uvijek podzastupljene u visokom obrazovanju naglašavajući važnost inkluzivnog pristupa u visokom obrazovanju ${ }^{6}$

U normativnim definicijama prava na visoko obrazovanje ${ }^{7}$, u pravilu se ističe da visoko obrazovanje mora biti dostupno svima na temelju »sposobnosti« te da se trebaju osigurati svi preduvjeti u visokom obrazovanju koji će pridonijeti primjeni ovih načela. Time se pred visoko obrazovanje postavljaju smjernice koje imaju za cilj umanjivanje nejednakosti i povećavanje razine znanja, vještina i kompetencija u društvu svakog pojedinca koji su presudni za osobni razvoj, poboljšanje kvalitete življenja i aktivnog uključivanja u društvo utemeljenom na znanju. Sukladno nizu politika, strategija i deklaracija na svjetskoj i europskoj razini donesenih tijekom zadnjeg desetljeća, upravo se od sveučilišta očekuje najveći doprinos u socijalnokulturološkoj dimenziji reformi i transformacija, čija je uloga presudna i u socijalnoj inkluziji.

U zaključku priopćenja ministra obrazovanja zemalja potpisnica Bolonjske deklaracije iz Londona 2008. godine, navodi se da bi visoko obrazovanje trebalo imati važnu ulogu u kreiranju inkluzivnog obrazovanja u visokom obrazovanju ${ }^{8}$. Zemlje članice Udruženja europskih sveučilišta (European Universities' Association - EUA) u svom dokumentu i cjeloživotnom učenju obvezale su se, između ostalog, da europska sveučilišta trebaju biti svjesna različitosti i individualnih potreba studenata i odgovorna su za prilagođavanje studijskih programa poštujući pristup poučavanju usmjeren studentu9.

${ }^{6}$ http://www.eua.be/pubs/engaging_in_lifelong_learning.pdf(12.05.2014.).

7 Primjerice Opća deklaracija o ljudskim pravima (1948.) i Povelja o temeljnim pravima Europske unije (2009.).

${ }^{8}$ Towards the European Higher Education Area: Responding to Challenges in a Globalised World (U susret europskom visokom obrazovanju: odgovori na izazove globaliziranog svijeta) (2007.).

${ }^{9}$ European Universities Charter on Lifelong Learning (Europska sveučilišna povelja o cjeloživotnom učenju), 2008.: 15. 
Zahvaljujući ciljevima Bolonjskog procesa, uključivanje podzastupljenih skupina među kojima su i studenti s invaliditetom u visoko obrazovanje više nije marginalna tema. Smjernice Bolonjskog procesa iz kategorije »socijalna dimenzija« odnose se na osiguravanje jednakih mogućnosti podzastupljenih skupina pri upisu studija, za vrijeme njegova trajanja, te pri završetku studija (Farnell, 2009.). lako se pojam »socijalna dimenzija« često koristio i prije, sve do 2007. godine nije bilo točne i općeprihvaćene definicije u visokom obrazovanju. U Bolonjskom procesu, socijalna dimenzija spominje se u svim ministarskim priopćenjima još od 2001. godine (European Universities Charter on Lifelong Learning, 2011.: 14) ${ }^{10}$. No, tek je u Londonu 2007. godine pojam sveobuhvatno definiran na način cilja da »studentska populacija koja upisuje, pohađa i završava visoko obrazovanje na svim razinama odražava različitost naših društava« i naglašavajući da "studenti (trebaju biti) u mogućnosti završiti studijske program bez prepreka koje proizlaze iz njihovog socijalnog i ekonomskog statusa." (Towards the European Higher Education Area: Responding to Challenges in a Globalised World, 2007.: 5). Od 2007. godine u sklopu Bolonjskog procesa »socijalna dimenzija« smatra se postupkom koji vodi do postizanja krovnog cilja (Key Issues for the European Higher Education Area - Social Dimension and Mobility, 2007.: 11) ${ }^{11}$ i stoga "golemim područjem aktivnosti u okviru kojeg vlade mogu provoditi svoje politike« (Modernisation of Higher Education in Europe: Funding and the Social Dimension, 2011.: 7).

Isticanje potrebe »socijalne dimenzije« visokog obrazovanja u Bolonjskom procesu, smjernice i mjere koje će provoditi spomenuto raspoređuju se na prva mjesto politika visokog obrazovanja do 2020. (Farnell, 2009.). Upravo ova činjenica ima direktne reperkusije na proces razvoja inkluzivnog pristupa visokog obrazovanja koji zahtijeva obvezu reformiranja obrazovnih sustava s ciljem smanjivanja društvenih nejednakosti i osiguravanjem svih preduvjeta povećanja pravednog pristupa visokom obrazovanju temeljenom na jednakim prilikama i potrebama svakog studenta. Na sastanku održanom u Leuven/Louvain/La-Neuve 2009. ministri visokog obrazovanja obvezali su se postaviti mjerljive ciljeve povećanja uključenosti podzastupljenih skupina u visoko obrazovanje, s ciljem realizacije do kraja idućeg desetljeća ${ }^{12}$.

U cilju povećanja uključenosti podzastupljenih skupina u visokom obrazovanju na međunarodnoj razini usvojene su mjere koje su podržale Europska komisija, Organizacija za ekonomsku suradnju i razvoj, Međunarodno udruženje sveučilišta

\footnotetext{
${ }^{10}$ Modernisation of Higher Education in Europe: Funding and the Social Dimension (Modernizacija visokog obrazovanja u Europi: financiranje socijalne dimenzije) (2011.).

${ }^{11}$ Key issues for the European Higher Education Area - Social Dimension and Mobility (Ključna pitanja europskog visokog obrazovanja - socijalna dimenzija i mobilnost) (2007.).

${ }^{12}$ Communiqué of the Conference of European Ministers Responsible for Higher Education (Službeno priopćenje Konferencije europskih ministara za visoko obrazovanje) (2009.).
} 
te Europski studentski zbor. Zajedničko svim zaključcima i inicijativama postavljenih mjera je promišljanje o strukturi studentskog tijela otvorenog pristupa visokom obrazovanju te načinima realizacije i uspješne inkluzije podzastupljenih skupina u visoko obrazovanje (Farnell i Kovač, 2010.).

Isticanje podzastupljenih skupina u visokom obrazovanju među kojima su i studenti s invaliditetom postavlja pred visoko obrazovanje zadatke osiguravanja kvalitetnog akademskog okruženja u cilju povećanja sudjelovanja studenata podzastupljenih skupina u visokom obrazovanju. Ono što doprinosi podizanju kvalitete pristupačnosti akademskog okruženja su spremnost od strane institucija visokog obrazovanja na kreiranje inkluzivnog i holističkog podučavanja i okruženja. Visokoškolske ustanove imaju obavezu poduzimanja aktivnosti koje imaju za cilj osiguravanje odgovarajućih prilagodbi i podrške sukladno iskazanim potrebama studenata, financijskim i drugim sredstavima institucije, odnosno praktičnosti potrebnih prilagodbi (Shevlin i O'Moore, 2000.). Osiguranje kvalitete akademskog okruženja ovisi o mogućnosti točne identifikacije potreba studenata, konzistentnost i stručnost u pristupu i dostupnosti usluga, jednakosti u pristupu resursima i postojanju inkluzivnog kulture i politike u visokoškolskim ustanovama (Vogel, 2004.).

Naglasak na preporukama proširivanja sudjelovanja podzastupljenih skupina u visokom obrazovanju koje su istaknute u svim politikama, deklaracijama i strategijama razvoja visokog obrazovanja na međunarodnoj razini, iako nisu obvezujuće, postaju vrlo utjecajne u procesu definiranja i oblikovanja nacionalnih javnih politika visokog obrazovanja. Poseban naglasak stavljen je na analizu trendova pristupa visokom obrazovanju, odnosno analizu nepravednosti u pristupu visokom obrazovanju pojedinih društvenih skupina u cilju identificiranja razloga i načina povećanja sudjelovanja podzastupljenih skupina u visokom obrazovanju. U preporuci Odbora ministara iz 2006., Vijeće Europe pozvalo je zemlje članice da »pridonesu praćenju socijalne dimenzije u visokom obrazovanju kako bi međunarodno usporedivi podaci o ovoj temi postali dostupni «13 (Preporuka Rec (2006) 5). Potreba za istraživanjima o socijalnoj dimenziji visokog obrazovanja, s ciljem usuglašavanja kriterija praćenja provedbe mjera socijalne dimenzije visokog obrazovanja i donošenja politike nije samo istaknuta u dokumentima Europske komisije ${ }^{14}$, nego i kod

\footnotetext{
${ }^{13}$ Preporuka (2006) 5 Odbora ministara državama članicama vezana uz Akcijski plan Vijeća Europe za promicanje prava i potpunog sudjelovanja u društvu osoba s invaliditetom: poboljšanje kvalitete života osoba s invaliditetom u Europi 2006.-2015. (2007.).

${ }^{14}$ Commission Staff Working Paper Accompanying the Report from the Commission to the Council on the Council Resolution of 23 November 2007 on Modernising Universities for Europe's Competitiveness in a Global Knowledge Economy (Popratni radni dokument djelatnika Komisije Izvješću Komisije Vijeća u vezi Rezolucije Vijeća od 23. studenog 2007. o modernizaciji sveučilišta za europsku kompetitivnost u globalnoj ekonomiji znanja) (2008.).
} 
brojnih drugih autora (Clancy, 2010;; Koucký, Bartušek i Kovařovic, 2010.; Eggins, 2009., Modernisation of Higher Education in Europe: Funding and the Social Dimension, 2011.)

Istovremeno Dolenec upozorava da, iako postoje pomaci, Bolonjski proces u deset godina nije napravio dovoljno u uključivanju podzastupljenih skupina na visoka učilišta, te da inkuzivna politika Bolonjskog procesa primarno još uvijek ima samo deklarativnu pobjedu, ali ne i provedbenu (Dolenec, 2010.).

Istraživanja pristupa visokom obrazovanju i uključenosti podzastupljenih skupina pokazuju da su sustavi visokog obrazovanja u većini zemalja poprilično udaljeni od postavljenih ciljeva i mjera europske politike. Razlike u pristupu, uključenosti, mjerama i završenosti studija u većini zemalja je vrlo nejednaka, kao i praćenje provedenih mjera (Clancy, 2010.), te prostora za daljnja istraživanja, kao i unapređenja, zasigurno ima.

Neki autori (Doolan, 2009.) uzroke tome vide u postojanju dvaju teorijskih pojmova institucionalnog habitusa visokog obrazovanja, tzv. inkluzivni institucionalni habitus visokog obrazovanja koji karakteriziraju institucionalne mjere koje doprinose osiguravanju jednakih obrazovnih mogućnosti i ekskluzivistički institucionalni habitus visokog obrazovanja koji još uvijek prikazuje socijalno neosjetljive institucionalne mjere. Uzroke nedostatka kreiranja inkluzivnog institucionalnog habitusa visokog obrazovanja možemo pronaći i u Bourdieuovoj raspravi o reproduciranju socijalnih nejednakosti u visokom obrazovanju. Naime, prema Bourdieuu, osnovna je svrha obrazovanja kontinuirana društvena reprodukcija segregacije koja se temelji na odnosima moći i povlasticama pojedinog društva. Upravo je, slijedeći logiku Bourdieuovog viđenja reprodukcije etabliranog poretka i inkluzija u visokom obrazovanju u okvirima nove paradigme, svojevrstan pokušaj upozoravanja na reproduciranje društvenih odnosa te pokušaj smanjivanja društvenih nejednakosti i pravednog pristupa visokom obrazovanju (Bourdieu, 1998.). Ukoliko se ne posveti veća pažnja socijalnom i kulturnom habitusu studenata, ne mogu se kreirati kvalitetne institucionalne mjere osiguravanja jednakog pristupa visokom obrazovanju (Bowers-Brown, 2006.; Greenbank, 2007.).

Istraživanje Divjaka i suradnika pokazuju da se uzroci mogu pronaći i u postignućima potencijalnih studenata u prijašnjem školovanju te da su slabija postignuća upravo onih s nižom razinom obrazovanja, što upućuje na potrebu redefiniranja obrazovnih sustava osnovne i srednjih škola u cilju smanjivanja razlika u postignućima učenika (Divjak i sur., 2008.), dok Redmond opisuje kao uzrok socioekonomski status obitelji, odnosno razvijanje tzv. akademskog habitusa u obitelji (Redmond, 2006.). Dokumenti u izdanju EUROSTAT-a otkrivaju da postoje velike razlike među državama članicama EU-a u definiranju podzastupljenih skupina, ali najčešće se spominju socioekonomski status, rod, invaliditet i etnička pripadnost. 
lako je razvidno da postoje različite nacionalne mjere poticanja povećanja podzastupljenih skupina u visoko obrazovanje među kojima su i studenti s invaliditetom, ne postoje rezultati učinka poduzetih mjera. ${ }^{15}$

\section{STUDENTI S INVALIDITETOM KAO PODZASTUPLJENA SKUPINA U VISOKOM OBRAZOVANJU}

lako je kategorija studenata s invaliditetom istaknuta kao podzastupljena skupina u visokom obrazovanju u većini država članica Europske unije, brojne poteškoće nastaje već u samom definiranju invaliditeta ${ }^{16}$, što posljedično utječe i na formiranja jasnih smjernica i mjera unapređenja postojećeg stanja.

Naime, izostankom zajedničke definicije, teško je utvrditi tko su sve studenti s invaliditetom, a otežana je i komparacija mjera različitih nacionalnih politika prema takvim studentima. Najčešći podaci o povećanju pristupa visokom obrazovanju temelje se na broju upisanih studenata s invaliditetom i analizi kvalitete akademskog okruženja koja se temelji na potrebi, primjerice, uklanjanje fizičkih prepreka za nesmetan pristup ustanovama i prilagodbi obrazovne infrastrukture i opreme. Posebne mjere kojima se pomaže studentima s invaliditetom obuhvaćaju osiguravanje upisnih mjesta, informativne programe te ciljno usmjeravanje i usluge vezane za podršku (Farnell i sur., 2011.). Međutim, značajno se postignuće ogleda se u tome što se iz analize podataka zemalja Europske unije može iščitati širi konsenzus oko osnovnih načela proširivanja sudjelovanja studenata s invaliditetom u visokom obrazovanju. To se, prije svega, odnosi na prepoznavanje potrebe nacionalnih vlada da postave proširivanje sudjelovanja studenata s invaliditetom kao jedan od prioriteta javnih politika visokog obrazovanja. Nadalje, postoji konsenzus oko toga da ovaj proces zahtijeva definiranje nacionalnih strategija i akcijskih planova, kao i alociranje dodatnih sredstava za provođenje mjera. Naglašena je, također, potreba za integriranim pristupom koji uzima u obzir sve uzroke nepravednosti u pristupu visokom obrazovanju studenata s invaliditetom, te da je prikupljanje podataka o uzrocima i stupnju nepravednosti u visokom obrazovanju nužan temelj za kvalitetne i ciljane javne politike u ovom području (Puzić, Doolan i Dolenec, 2006.).

Analiza dostupnih podataka pojedinih zemalja Europske unije jasno pokazuju da u većini zemalja postoje potrebe osiguravanja preduvjeta povećanja pristupa visokom obrazovanju studenata s invaliditetom, te da upravo zahvaljujući postavljenim strateškim ciljevima visokog obrazovanja na međunarodnoj razini uključivanje studenata s invaliditetom u visoko obrazovanje više nije marginalna tema.

${ }^{15}$ The Bologna Process in Higher Education in Europe. Key indicators on the social dimension and mobility (Bolonjski proces u visokom obrazovanju. Ključni pokazatelji socijalne dimenzije i mobilnosti) (2009.).

${ }^{16}$ New Skills for New Jobs: Action Now (Nove vještine za nove poslove) (2010.). 
Tako, Mađarska i Slovenija navode kao prioritet poduzimanje mjera kojima bi se riješio manjak posebne obrazovne opreme za studente s invaliditetom. U Velikoj Britaniji visoka učilišta imaju obvezu osigurati »razumne prilagodbe« za potrebe studenata s invaliditetom i unaprijed rade planove kako bi se uklonile potencijalne prepreke koje otežavaju pristup studentima s invaliditetom. Estonija je izrazila zabrinutost zbog nedovoljnog razumijevanja potreba studenata s invaliditetom, navodeći da nastavnici i studenti često nisu osviješteni kad je riječ o potrebama osoba s invaliditetom te se kao posljedica ne poduzimaju odgovarajuće mjere. $U$ Grčkoj, učenici sa zdravstvenim problemima imaju pravo premještaja na sveučilište najbliže mjestu stanovanja.

Danska primjenjuje koncept prema kojem studenti s fizičkim i psihološkim poteškoćama mogu dobiti podršku kroz sustav studentskih potpora, ali pod uvjetom da se studenti s invaliditetom aktivno uključe u utvrđivanju prepreka i predstavljanju svojih potreba. U Danskoj se podrška studentima s invaliditetom, umjesto mjera za cijelu kategoriju studenata s invaliditetom, nastoji pružiti kroz sustav ciljanih individualnih studentskih potpora. Mnoga austrijska i njemačka sveučilišta imaju službenike za studente s invaliditetom koji pružaju savjetovanje, pomažu u slučaju diskriminacije, te nude informacije o dodatnim financijskim mjerama. U Sloveniji većina visokih učilišta ima zaposlenika zaduženog za rad sa studentima s posebnim potrebama, te sustav individualne podrške u nastavi koju provode i studenti i nastavnici. Na sveučilištima u Škotskoj, Engleskoj, Irskoj razvijen je sustav podrške savjetnika mentora koji kroz program vršnjačke podrške pruža pomoć u pružanju informacija, pomoći u učenju, procedure studiranja, te praćenja studiranja. Sustavi podrške za osobe s invaliditetom na sveučilištima u Španjolskoj, Švicarskoj, Njemačkoj i Engleskoj sustavni su oblici podrške koji pružaju širok spektar usluga prema specifičnim potrebama studenta s invaliditetom od specijalizirane opreme, angažiranja asistenata za pomoć u praćenju nastave, razgovora do pružanja podrške nastavnicima u prilagođavanju nastave $\mathrm{i}$ ispita specifičnim potrebama svakog studenta. Ujedno, služba pruža podršku i u aktivnom uključivanju studenata s invaliditetom u život akademske zajednice osiguravanjem neophodnih uvjeta za uključivanje u svakodnevni život. "Socijalna zajednica« oblik je podrške prisutan na sveučilištima u Australiji, Španjolskoj, Švedskoj temeljen na sustavu podrške različitim potrebama studenata, uključujući podršku studentima s invaliditetom na principima jednakosti i nediskriminacije. Aktivnosti se temelje na okupljanju tima studenata koji pruža individualne podrške studentima različitih vjera, rasa, socijalnog statusa, studentima s invaliditetom u cilju podržavanja jednakosti studenata kroz promoviranje tolerancije i isticanje značaja inkluzivne akademske zajednice. Ujedno, »socijalne zajednice« u navedenim zemljama provode aktivnosti edukacije cjelokupne akademske zajednice s naglaskom na senzibilizaciju zajednice na 
različitost i sprečavanja diskriminacije (Služba za podršku studentima - analiza opcija, 2013.).

I pored ostvarenih različitih mjera koje imaju za cilj povećanje sudjelovanja studenata $s$ invaliditetom u visoko obrazovanje, razvijenih sustava podrške na sveučilištima u zemljama Europske unije, iskustva studenata s invaliditetom o kvaliteti akademskog okruženja su različita. Mali broj istraživanja o kvaliteti visokog obrazovanja studenata s invaliditetom pokazuju da još uvijek postoje objektivne prepreke i nedostatak sustavne podrške od strane sveučilišta (Fleischer, Adolfsson i Granlund, 2013.). Istraživanje provedeno u Velikoj Britaniji sa studentima s invaliditetom i studentima bez invaliditeta o provođenju inkluzivnog pristupa u visokom obrazovanju pokazalo je da se studenti s invaliditetom susreću s barijerama u praćenju nastave i izvršavanja obaveza (Madriaga i sur., 2010.).

S obzirom da zemlje ne samo da kombiniraju različite mjere, već i prate različite aspekte kvalitete visokog obrazovanja studenata s invaliditetom, teško je procijeniti kvalitetu mjera povećanja sudjelovanja studenata s invaliditetom u visokom obrazovanju na europskoj razini. Zbog toga nedostaju analize utjecaja mjera za povećanje uključenosti i analizu kvalitete provedbe postavljenih mjera kojima bi se omogućilo kreiranje standarda i postavljanje jasnih smjernica koje će doprinijeti povećanju sudjelovanja studenata s invaliditetom u visokom obrazovanju.

Smjernice su: zabrana diskriminacije, zaštita akademskih standarda, individualizacija u pristupu, ravnopravnost i pravednost, dostupnost informacija i usluga, zaštita osobnih podataka, razumna prilagodba, prava i osobne odgovornosti ${ }^{17}$. Nakon definiranja prava na obrazovanje i jednakosti prilika potrebno je ova prava i načela pretvoriti u mjere koje će u stvarnosti osigurati pristup obrazovanju za studente $s$ invaliditetom. Dolazi se, dakle, do obrazovne politike, a u ovom području pojam »inkluzivno obrazovanje« označava onaj koncept koji brojne vlade diljem svijeta koriste prilikom izrade svojih obrazovnih politika.

Četiri su osnovne dimenzije obrazovanja koje prema mišljenju Katarine Tomaševski (2006.), prve izaslanice Ujedinjenih naroda za pravo na obrazovanje (1998. - 2004.), moraju biti zadovoljene kako bi se pravo na obrazovanje ispunjavalo i u praksi, to su: raspoloživost, pristupačnost, prihvatljivost i prilagodljivost.

Raspoloživost polazi od zadaća pravnih, strateških i financijskih okvira u kojima će naglasak na osiguravanje jednakih mogućnosti biti popraćen adekvatnim mjerama osiguravanja obrazovnih ustanova koje su adekvatno regionalno distribuirane i opremljene za inkluzivno obrazovanje. Raspoloživost polazi od kulture osiguravanja kvalitete visokog obrazovanja, univerzalnog dizajna za učenje i spre-

${ }_{17}$ Council Resolution of 5 May 2003 on Equal Opportunities for Pupils and Students with Disabilities in Education and Training (Rezolucija Vijeća o jednakim mogućnostima za učenike i studente s invaliditetom u obrazovanju i naobrazbi) (2003.). 
mnost svih aktera u obrazovanju na osiguravanje jednakog pristupa u obrazovanju.

Pristupačnost financiranja aktivnosti u svrhu izjednačavanja i osiguravanja jednakosti pristupa visokom obrazovanju svima, posebno ranjivim skupinama kroz sustave osiguravanja sufinanciranja i praćenja potreba te osiguravanje dostupnosti informacija o financijskoj podršci sustavu i pojedincima kojima će se osigurati kvalitetno visoko obrazovanje. Prilagodljivost se očituje u kreiranju kvalitetnog pristupačnog akademskog okruženja koje osigurava studentima prilagodbe nastavnih metoda i omogućava dostupnost akademskih aktivnosti na način da ne kompromitiraju akademske standarde.

Osiguravanjem minimalnih standarda kvalitete visokog obrazovanja i sustavnim praćenjem provedbi zajedničkih smjernica i mjera osiguravanja kvalitete programa visokog obrazovanja s posebnim naglaskom na aktivno uključivanje studenata u kreiranju i praćenju osiguravaju se uvjeti studiranja koji za ishode imaju kvalitetne izlazne kompetencije studenata. Kreiranjem dimenzije prihvatljivosti, osigurava se socijalna kompetencija svih aktera u obrazovnom procesu i na taj način kvalitetu visokog obrazovanja.

\section{STUDENTI S INVALIDITETOM U HRVATSKOJ}

lako osobe s invaliditetom predstavljaju značajan udio populacije u Hrvatskoj, u visokom obrazovanju još uvijek su neadekvatno zastupljeni. Prema Hrvatskom registru osoba s invaliditetom, u Hrvatskoj je s danom 13. siječnja 2014. zabilježeno 525782 osoba s invaliditetom. Prema podacima istog registra, broj studenata s invaliditetom je 424 što upućuje na mali broj studenata s invaliditetom u visokom obrazovanju (Izvješće Pravobraniteljice za osobe s invaliditetom, 2013.) U istraživanju Eurostudent za Hrvatsku, 2012., ne postoje točni podaci o broju studenata s invaliditetom, ali podaci ukazuju na to da oko $7 \%$ studenata boluje od kronične bolesti ili ima fizičke ili mentalne teškoće (izračun na temelju Farnell i sur., 2012.). Premda ne postoje pouzdani podaci na temelju kojih bi se mogla izvesti nacionalna ili međunarodna usporedba udjela studenata s invaliditetom u odnosu na broj studenata, podzastupljenost ovih skupina studenata je uobičajena u međunarodnim okvirima (Santiago i sur., 2008.). U Hrvatskoj, kao ni u ostalim državama EU-a, ne postoji normativna definicija studenata s invaliditetom. U Hrvatskoj se pojam studenta s invaliditetom obrađuje u okviru dokumenta Osiguravanje minimalnih standarda pristupačnosti visokog obrazovanja za studente s invaliditetom na sveučilištima članicama (2013). Na osnovi te definicije studenti s invaliditetom smatraju se studenti s oštećenjem vida i sluha, motoričkim poremećajima, kroničnim bolestima, specifičnim teškoćama učenja i psihičkim bolestima i poremećajima. Defini- 
cija jasno ukazuje na heterogenost specifičnih potreba studenata s invaliditetom, sukladno heterogenosti invaliditeta i individualnih potreba, te osiguravanja mjera koje će doprinijeti kvaliteti visokog obrazovanja studenata s invaliditetom.

Kvaliteta visokog obrazovanja studenata s invaliditetom u Hrvatskoj može se iščitati s gledišta zakonodavstva, gledišta provedenih mjera osiguravanja kvalitete te istraživanja koja pokazuju stupanj kvalitete visokog obrazovanja studenata s invaliditetom. $U$ visokom obrazovanju »osiguravanje kvalitete« sveobuhvatan je izraz koji uključuje politiku, procese, aktivnosti, mehanizme kojima se priznaje i razvija kvaliteta visokog obrazovanja (Ivković, 2009.).

\section{Zakonska regulativa visokog obrazovanja studenata s invaliditetom}

Zakonska regulativa prava na obrazovanje zastupljena je u svim relevantnim zakonskim okvirima Republike Hrvatske. Ustav Republike Hrvatske ${ }^{18}$ i na temelju njega doneseni Zakon o znanstvenoj djelatnosti i visokom obrazovanju ${ }^{19}$ i Zakon o osiguravanju kvalitete u znanosti i visokom obrazovanju ${ }^{20}$, koji sadrže velik dio međunarodno propisanih standarda iz područja prava na obrazovanje, uključila su sva načela prava na obrazovanje za sve pa tako i visoko obrazovanje. Osim Zakona o suzbijanju diskriminacije ${ }^{21}$, postoje i brojne strategije i programi Vlade Republike Hrvatske ili pojedinih ministarstava koji uključuju mjere za osiguranje jednakog pristupa visokom obrazovanju. ${ }^{22}$

Nacionalna strategija za izjednačavanje mogućnosti za osobe s invaliditetom od 2007. do 2015. godine ${ }^{23}$ i Strateški plan Ministarstva socijalne politike i mladih 2014. - 2016 ${ }^{24}$. također su usklađeni s relevantnim međunarodnim dokumentima, posebno u onom dijelu koji se odnosi na odgoj i obrazovanje, ističući važnost kvalitetnog obrazovanje na svim razinama. Navodi se i nužnost osiguravanja uvjeta za povećanje pristupa osobama s invaliditetom kvalitetnom visokom obrazovanju.

Ministarstvo znanosti, obrazovanja i sporta je temeljem Zakona o znanstvenoj djelatnosti i visokom obrazovanju i Sporazuma o poticajnim mjerama za upis u

\footnotetext{
${ }^{18}$ Ustav Republike Hrvatske (NN, 56/90, 135/97, 8/89, 113/99, 124/00, 28/01, 41/01, 55/01, 76/10, 85/10, 05/14).

${ }^{19}$ Zakon o znanstvenoj djelatnosti i visokom obrazovanju (NN, 123/03, 198/03, 105/04, 174/04, 46/07, 45/09, 64/11, 94/13 i 139/13).

${ }^{20}$ Zakon o osiguravanju kvalitete u znanosti i visokom obrazovanju (NN, 45/09).

${ }^{21}$ Zakon o suzbijanju diskriminacije (NN, 85/08).

22 Plan razvoja sustava odgoja i obrazovanja 2005.-2010., Nacionalni program djelovanja za mlade 2010., Zajednički memorandum o socijalnom uključivanju Republike Hrvatske, 2007., Strateški plan Ministarstva znanosti, obrazovanja i sporta 2014.-2016. itd.

${ }^{23}$ Nacionalna strategija za izjednačavanje mogućnosti za osobe s invaliditetom od 2007. do 2015. (NN, 63/07).

${ }^{24}$ Strateški plan za razdoblje od 2013. do 2015. godine Ministarstva socijalne politike i mladih (2012).
} 
ustanove visokog obrazovanja od 27. ožujka 2007. omogućilo upis na studij bez plaćanja za sve studente s $60 \%$ i više posto invaliditeta (ukoliko pređu razredbeni prag). Od 2003. godine uvedena je posebna kategorija »《 za studente s invaliditetom u kojoj svi studenti s invaliditetom ostvaruju pravo na stipendiju (Osiguravanje minimalnih standarda pristupačnosti visokog obrazovanja za studente $s$ invaliditetom na sveučilištima članicama, 2013.). Na taj način stvorili su se pozitivni zakonski preduvjeti koji imaju za cilj povećanje broja studenata s invaliditetom na visokim učilištima, a time i osiguravanje nastavka školovanja mladih s invaliditetom. Uvidom u statute triju najvećih sveučilišta u Hrvatskoj (Zagreb, Rijeka, Split), vidljivo je da su sveučilišta u svoje statute ugradila norme kojim jamče prava na jednak pristup visokom obrazovanju svima te sukladno tome preuzela obvezu osiguravanja svih prava i mogućnosti koje student s invaliditetom može ostvariti na tim sveučilištima ${ }^{25}$. Sukladno tome, studenti s invaliditetom imaju pravo na individualno prilagođen način polaganja ispita, dodatne provjere za upis na fakultet te ispite tijekom studija ako ostvaruju prava kao student s invaliditetom. Studenti s invaliditetom imaju pravo oslobođenja od plaćanja troškova studija ako su upisani u prvu godinu studiranja u statusu redovitog studenta. Ujedno, ostvaruju pravo na izravno dobivanje mjesta u studentskom domu, pravo na naknadu dijela troškova prijevoza koje sufinancira Ministarstvo znanosti, obrazovanja i sporta Republike Hrvatske, mogućnost dobivanja stipendije na osnovi invaliditeta koje dodjeljuje Nacionalna zaklada za potporu učeničkom i studentskom standardu. Sveučilišta u Rijeci i Zagrebu osiguravaju mogućnost prijevoza studenata s tjelesnim invaliditetom organiziranim prijevozom u suradnji s Udrugama studenata s invaliditetom.

Hrvatska zakonodavna regulativa obrazovanja obvezuje sve subjekte na ostvarivanje preduvjeta prava osoba s invaliditetom na obrazovanje, bez diskriminacije i na osnovi jednakih mogućnosti, ali dostupni rezultati ostvarenih mjera u visokom obrazovanju još uvijek ne pokazuju povećanje sudjelovanja studenata s invaliditetom u visokom obrazovanju.

\section{Analiza mjera osiguravanja kvalitete visokog obrazovanja studenata s invaliditetom}

Brojni pokazatelji ukazuju da poduzete mjere još uvijek nisu dostatne i da je akademsko okruženje na većini učilišta još uvijek prepreka kvalitetnom uključivanju studenata s invaliditetom u visoko obrazovanje u Hrvatskoj. Još uvijek ne postoji sustavno vođenje podataka o studentima s invaliditetom. Podaci na temelju provedene ankete na 93 sastavnice visokih učilišta pokazali su da na velikom broju

${ }^{25}$ Statut Sveučilišta u Zagrebu, 2009.; Statut Sveučilišta u Rijeci, 2008.; Statut Sveučilišta u Splitu, 2009. 
učilišta prepreke studentima s invaliditetom predstavljaju arhitektonske barijere, nedostupnost tehničke podrške, nepripremljenost nastavnog i nenastavnog osoblja za rad sa studentima s invaliditetom, nedostatak službi podrške, nedostatak financijskih sredstava u cilju podizanja kvalitete akademskog okruženja. ${ }^{26}$ Ujedno, analiza stanja i potreba za osiguravanjem pristupačnosti visokog obrazovanja za studente s invaliditetom u sklopu Prijedloga osiguravanja minimalnih standarda pristupačnosti visokog obrazovanja ističe da pored primjera dobre prakse, na nekim visokim učilištima postoje još uvijek izražene prepreke od nedostatnosti informacija, neprilagođenosti nastavnog procesa potrebama studenata s invaliditetom, nedostatka sustavne podrške do nedostatka asistenata. lako postoje uredi za studente $s$ invaliditetom i koordinatori za studente s invaliditetom, na nekim visokim učilištima još uvijek te službe nemaju odgovarajuće resurse za rad, odnosno još uvijek ne postoji niti na jednom sveučilištu u Hrvatskoj služba za pružanje sustavne podrške studentima s invaliditetom. ${ }^{27}$

Prema Izvješću Pravobraniteljice za osobe s invaliditetom 2013. godine, postoje još uvijek izražene teškoće i kršenja prava osoba s invaliditetom na obrazovanje do kojih u praksi dovodi nepostojanje procedura koje bi regulirale određivanje vrste podrške za studiranje i načine njezina pružanja kao i prohodnosti u sustavu visokog obrazovanja. Zbog nedostatnosti zakonodavnih mjera o osiguravanju minimalnih standarda u visokom obrazovanju nisu regulirani način i vrste podrške te razumne prilagodbe studentima $s$ invaliditetom kao ni procedura kojom se ona ostvaruje. Na sveučilištima u sklopu ureda za studente $s$ invaliditetom ne postoje službe stručne procjene individualnih potreba studenata $s$ invaliditetom koje proizlaze iz zdravstvenog stanja i/ili invaliditeta. Na osnovi takve stručne procjene osigurala bi se razumna prilagodba i izjednačavanje mogućnosti u ispunjavanju očekivanih akademskih standarda. Uslijed nedostatka sustavnih rješenja, osiguravanje potrebne podrške prepušteno je dobroj volji pojedinih nastavnika što može dovesti do diskriminacije propuštanjem razumne prilagodbe ili dovodi do snižavanja akademskih standarda što je također neprihvatljivo. U Izvješću, nadalje, navodi se da se znatan broj pritužbi studenata s invaliditetom u 2013. odnosio se na teškoće u ostvarivanju stipendije, smještaja u studentski dom i upisa na prvu godinu studija što ukazuje na nedostatne informiranosti samih studenata o propisanim postupcima i njihovim rokovima što upućuje da se mladi s invaliditetom susreću s nizom propisa i odredaba koje su dovele do nesnalaženja i određenih propusta i zakašnjelih reakcija na koje su institucije imale razumijevanja i reagirale fleksibilno.

\footnotetext{
${ }^{26}$ Izvješće Pravobraniteljice za osobe s invaliditetom o visokom obrazovanju studenata s invaliditetom (2012.).

${ }^{27}$ Tempus projekt »EDU Quality - Education for Equal Opportunities at Croatian Universities« (2009.).
} 
Kao negativna pojava zabilježena je u 2013. odredba Zakona o socijalnoj skr$\mathrm{bi}^{28} \mathrm{koji}$ onemogućava studentima s invaliditetom da primaju osobnu invalidninu ukoliko istovremeno ostvare pravo na studentsku stipendiju iako je svrha osobne invalidnine istim zakonom definirana kao zadovoljavanje životnih potreba za uključivanje u svakodnevni život zajednice. To ih dovodi u situaciju da moraju birati između invalidnine i stipendije što dodatno pogoršava njihovu tešku ekonomskosocijalnu situaciju. Takva politika, umjesto aktiviranja osoba s invaliditetom, vodi u njihovu pasivizaciju kroz destimuliranje obrazovanja kao preduvjeta zapošljavanju. U velikom broju slučajeva osobna invalidnina koju ostvaruju osobe s invaliditetom predstavlja jedini siguran prihod za ostvarivanje životnih potreba. Sukladno velikom postotku nezaposlenosti ove populacije, osobe $s$ invaliditetom teško se odlučuju za nastavak školovanja ili različite oblike zapošljavanja ukoliko je to povezano s gubljenjem navedenog prava na osobnu invalidninu. To uzrokuje da osobe s invaliditetom vrlo rano završavaju školovanje, najčešće završetkom srednje škole, a sukladno niskoj razini kvalifikacija, nepovoljan položaj na otvorenom tržištu rada te otežano aktivno uključivanje u život zajednice. Posljedica je ponovna ovisnosti o zadovoljavanju životnih potreba kroz sustav socijalnih prava i nepovoljan položaj u društvu (Izvješće Pravobraniteljice o osobama s invaliditetom Republike Hrvatske, 2013.). Nakon velikog broja pritužbi, ta odredba je zakonom ukinuta vrlo brzo, međutim nije utvrđeno koliko je utjecala na odluke mladih s invaliditetom da se upišu na studij, odnosno koliko je utjecala na odustajanje studenata od studiranja.

\section{Istraživanja kvalitete visokog obrazovanja studenata s invaliditetom}

U malobrojnim istraživanjima kvalitete visokog obrazovanja studenata s invaliditetom koja su provedena na visokim učilištima u Hrvatskoj, posebno se ističe nedostatnost pristupačnosti informacijama studentima s invaliditetom, nedostatka formalne podrške od strane tijela učilišta, neprilagođenost obrazovnih materijala specifičnim potrebama studenata s invaliditetom i nepripremljenosti nastavnog $\mathrm{i}$ nenastavnog osoblja za rad sa studentima s invaliditetom (Fejzić, 2007.). Franulović u svom istraživanju pokazuje da su studenti s invaliditetom zadovoljni sustavom obrazovanja, opsegom prava u obrazovanju, ali nisu zadovoljni izvođenjem nastave, prilagođenošću opreme i nastavnim pomagalima (Franulović, 2009.).

Osim toga, i nacionalno izvješće istraživanja Eurostudent za Hrvatsku (Farnell i sur., 2011.) pokazuje rezultate istraživanja u kojem 15\% svih studenata koji su učestvovali u istraživanju (realizirani uzorak istraživanja iznosio je 4664 studenata) na-

\footnotetext{
${ }^{28}$ Zakon o socijalnoj skrbi (NN, 157/13).
} 
vodi da ima neku zdravstvenu teškoću ili invaliditet koji negativno utječu na tijek njihovog studija. Studenti kao najčešću teškoću koja ih ometa tijekom njihovog studija navode kategoriju akademskog okruženja. U velikoj mjeri smatraju kako se uopće ne vodi računa o njihovim potrebama (43\% navodi kako se uopće ne vodi računa, a $25 \%$ kako se ne vodi računa). Tek $4 \%$ studenata s teškoćama navodi kako se o njihovim potrebama jako vodi računa. Podaci pokazuju da postoji potreba za sustavom podrške studentima s teškoćama i osiguravanje kvalitete akademskog okruženja. Prema podacima istog istraživanja za Hrvatsku, kad je riječ o procjeni studenata s invaliditetom u kojoj mjeri institucije visokog obrazovanja vode računa o njihovim teškoćama tijekom studija, $68 \%$ ovih studenata smatra kako se o njihovim teškoćama vodi nedovoljno ili nimalo računa (Farnell i sur., 2012.). Studenti s invaliditetom nezadovoljni su prilagodbom nastave i studijskih obveza i smatraju da imaju iskustvo znatno većeg studijskog opterećenja u odnosu na druge studente, unatoč tomu što na predavanjima provode približno jednak broj sati (Farnell i sur., 2012.). Izraženo je i nezadovoljstvo studenata s invaliditetom kvalitetom studijskih programa i smatraju da studij neće doprinijeti njihovoj budućoj zapošljivosti niti da studij stvara dobre temelje za osobni razvoj. Studenti s invaliditetom također su financijski opterećeniji u odnosu na ostale studente (File i sur., 2013.), što je u skladu s činjenicom da su im životni troškovi viši u odnosu na pojedince bez fizičkih ili mentalnih teškoća, osobito kad je riječ o stanovanju i zdravstvenoj skrbi (Farnell i sur., 2012.). U istraživanju o percepciji mlađeg nastavnog kadra o pristupačnosti visokoškolske nastave studentima s invaliditetom na Edukacijsko-rehabilitacijskom fakultetu Sveučilišta u Zagrebu, rezultati su pokazali potrebu stjecanja specifičnih kompetencija za rad u nastavi prema načelima univerzalnog dizajna za učenje. Ujedno, istraživanje je pokazalo da stavovi, iskustva i prethodna znanja o osobama $s$ invaliditetom znatno doprinose načinu postupanja mlađeg nastavničkog kadra prema studentima s invaliditetom (Fajdetić, Kiš-Glavaš i Lisak, 2013.). U istraživanju u koje su bili uključeni koordinatori za studente s invaliditetom, dobiveni podaci pokazuju da koordinatori smatraju da je došlo do pomaka u pristupu studentima s invaliditetom, ali i da je potrebna edukacija nastavnog i administrativnog osoblja, senzibiliziranost društva, te rad na učinkovitosti razumne prilagodbe za studente s invaliditetom (Krznarić, 2013.).

\section{ZAKLJUČNA RAZMATRANJA}

Načelo jednakih mogućnosti prisutno je u prostoru javnih politika obrazovanja u Hrvatskoj i ne može se osporiti da je došlo do stanovitih pomaka. Sukladno postavljenim strateškim i normativnim rješenjima, provedene su različite mjere 
koje su dovele do stvaranja preduvjeta povećanja broja studenata s invaliditetom na visokim učilištima u Hrvatskoj.

U sklopu projektnih aktivnosti TEMPUS projekta ${ }^{29}$ čiji je cilj izjednačavanje mogućnosti za studente s invaliditetom u visokom obrazovanju u Republici Hrvatskoj, otvoreni su uredi za studente s invaliditetom na šest sveučilišta u Hrvatskoj, donesene su osnovne smjernice osiguravanja pristupa studentima $s$ invaliditetom, izrađeni su pravni i strateški ciljevi pristupačnosti visokog obrazovanja, osigurane su prijavne i upisne procedure, stipendije, pravo na organizirani prijevoz te su stvoreni svi preduvjeti kreiranja kvalitetnog akademskog okruženja (Izvješće Pravobraniteljice za osobe $s$ invaliditetom, 2012.).

Udruge za studente $s$ invaliditetom neizostavan su sustav podrške koji kroz rad i aktivnosti poticanja mladih s invaliditetom na uključivanje u sustav obrazovanja pružaju usluge informiranja i savjetovanja mladih, pružaju potrebnu tehničku i materijalnu podršku u cilju aktivnog uključivanje studenata s invaliditetom u aktivnosti vezane uz aktivno sudjelovanje $u$ akademskoj zajednici (npr. Udruga "ZNAM«, »ZAMISLI« itd.).

Ono što još nedostaje su konkretne mjere nadležnih institucija zacrtane u zakonskim odredbama, nepostojanje jedinstvene definicije osobe s invaliditetom, odnosno dokazivanja statusa osobe s invaliditetom, jedinstvene definicije studenata s invaliditetom, kulture osiguravanja kvalitete akademskog okruženja, sustavi financiranja poboljšanja kvalitete akademskog okruženja, dokument jedinstvenih standarda pristupačnosti i osiguravanje sustavne potpore za ostvarivanje jednakih mogućnosti za osobe s invaliditetom u visokom obrazovanju. Nedostaju i empirijska istraživanja, sustavno praćenje provođenja mjera i dovoljno jasno vidljiva društvena akcija usmjerena na potrebe studenata s invaliditetom koji se uključuju u sustav visokog obrazovanja. Nedostatne su i analize kvalitete provedbe postojećih mjera, kao i aktivno uključivanje studenata s invaliditetom u analizu kvalitete visokog obrazovanja i kreiranje modela visokog obrazovanja za studente $s$ invaliditetom. To je vrlo značajno i predstavlja polazište u kreiranju pozitivnih mjera u poboljšanju kvalitete visokog obrazovanja studenata s invaliditetom. Pokazatelji ostvarenih mjera mogu se iščitati iz podataka broja studenata s invaliditetom, potražnje za programima, raspoloživim resursima, uspjehom studenata s invaliditetom, završavanja programa kao i sustavno ispitivanje i uvažavanje stavova studenata s invaliditetom o kvaliteti akademskog okruženja (Sinković i Sinković, 2008.).

U Prijedlogu Minimalnih standarda pristupačnosti visokog obrazovanja za studente s invaliditetom u Republici Hrvatskoj, 2013., na osnovi analize postojećeg

${ }^{29}$ Tempus projekt »EDU Quality - Education for Equal Opportunities at Croatian Universities« (2009.). Nositelj projekta je Sveučilište u Zagrebu, partneri su Sveučilišta u Rijeci, Splitu, Osijeku, Zadru i Dubrovniku. 
stanja postavljene su smjernice u cilju osiguravanja kvalitete visokog obrazovanja studenata s invaliditetom.

Uvidom $\mathrm{u}$ istaknute smjernice jasno su postavljene mjere kreiranja pravnog, strateškog i financijskog okvira temeljenog na socijalnoj dimenziji visokog obrazovanja kao jednoj od osnovnih načela visokog obrazovanja u novim zakonima koji obuhvaćaju visoko obrazovanje. Nadalje, naglašena je potreba povećanja upisa studenata s invaliditetom temeljenih na dostupnosti, prilagođenosti i jedinstvenosti informacija važnih budućim studentima s invaliditetom za donošenje odluke o izboru i upisu studijskog programa. Jedan od najznačajnijih preduvjeta kreiranja nastave $\mathrm{i}$ ishoda učenja u skladu s potrebama studenata s invaliditetom je educirano i senzibilizirano nastavno, stručno i administrativno osoblje na visokim učilištima kroz različite oblike formalnog ili neformalnog obrazovanja i sustava podrške svih u obrazovnom procesu. Kao jedna od istaknutih mjera je organizacija odgovarajućih oblika institucionalne potpore studentima s invaliditetom u obliku službi, ureda/ službe/ureda/odgovorne osobe na svim visokim učilištima u Republici Hrvatskoj, u skladu s potrebama i specifičnostima svake pojedine ustanove. Ujedno, istaknuta je potreba osiguravanja prostorne pristupačnosti visokih učilišta, organizacije prijevoza u suradnji s jedinicama lokalne samouprave te povećanja prilagođenih smještajnih kapaciteta u studentskim domovima studentima s invaliditetom.

U Izvješću Pravobraniteljice za osobe s invaliditetom, 2013., postavljene su preporuke kojima bi se osiguralo povećanje sudjelovanja studenata s invaliditetom na visokim učilištima. Potrebno je usvojiti zakonodavstvo kojim bi se zajamčilo osiguravanje odgovarajuće podrške studentima s invaliditetom i jasno propisali načini njezina ostvarivanja kao i dužnosti svih dionika u procesu. Uvođenjem profesionalnog usmjeravanja, odnosno stručne službe, procjene sposobnosti budućih studenata s invaliditetom pomogle bi u odabiru zanimanja i procjeni potrebnih oblika podrške i razumnih prilagodbi. Prvi korak u smjeru donošenja zakonodavnih mjera bilo bi donošenje Strategije znanosti i obrazovanja u kojoj se navodi potreba i veća uključenost nadležnog ministarstva. Stoga pomaci u Nacrtu Strategije obrazovanja, znanosti i tehnologije, 2013., obećavaju jer je to prvi strateški dokument koji govori o studentima s invaliditetom.

Istraživanja Eurostudenta o socijalnoj dimenziji visokog obrazovanja u EU, 2012., ističe potrebu usuglašavanja elemenata praćenja kvalitete visokog obrazovanja studenata s invaliditetom u svim zemljama Europske unije.

Kvalitetni podaci analize visokog obrazovanja studenata s invaliditetom omogućit će kreiranje standarda osiguravanja jednakih mogućnosti visokog obrazovanja studenata $s$ invaliditetom, praćenje napretka prema usvojenim ciljevima te ispunjavanje obveza proizašlih iz ratificiranih nacionalnih i međunarodnih dokumenata.

\section{2 članci}


LITERATURA

1. Bourdieu, P. (1998). Practical reason. Cambridge: Polity.

2. Bowers-Brown, T. (2006). Widening participation in higher education amongst students from disadvantaged socio-economic groups. Tertiary Education and Management, 12 (1), 59-74.

3. Clancy, P. (2010). Measuring access and equity from a comparative perspective. In Eggins, H. (ed.), Access and equity. Comparative perspectives. Rotterdam: Sense Publishers, 69-102.

4. Clark, C., Dayson, A. \& Millward, A. J. (2002). Theorising special education. New York: Routledge Falmer.

5. Commission staff working paper accompanying the Report from the Commission to the Council on the Council Resolution of 23 November 2007 on Modernising Universities for Europe's competitiveness in a global knowledge economy. COM (2008) 680 final (2008). Brussels: European Commission. Preuzeto s: http://ec.europa.eu/education/higher-education/ doc/com/sec2719_en.pdf (01.06.2014.).

6. Communiqué of the Conference of European Ministers Responsible for Higher Education (2009). Preuzeto s: http://www.ond.vlaanderen.be/hogeronderwijs/bologna/conference/documents/leuven_louvain-la-neuve_ communiqu\%C3\%A9_april_2009.pdf (19.06.2014.).

7. Council Resolution of 5 May 2003 on equal opportunities for pupils and students with disabilities in education and training (2003). Official Journal of the European Communities, C 134/6 (2003/C 134/04.).

8. Divjak, B., Horvatek, R. \& Vidaček-Hainš, V. (2008). Kolumna Pravo na obrazovanja: "Politike jednakog pristupa visokom obrazovanju i njihova implementacija u suradnji svih dionika društva» (1. dio). Zagreb: Institut za razvoj obrazovanja. Preuzeto s: http://www.iro.hr/hr/javne-politike-visokog obrazovanja/kolumna/socijalno-neosjetljive-prakse/ (15.05.2014.).

9. Dolenec, D. (2010). Kolumna Pravo na obrazovanje: "Snimka Lisabonskog procesa: izvori nejednakosti u obrazovanju«. Zagreb: Institut za razvoj obrazovanja. Preuzeto s: http://www.iro.hr/userdocs/File/pno_kolumna/Snimka_Lisabonskog_procesa.pdf (19.05.2014.).

10. Doolan, K. (2009). Kolumna Javne politike visokog obrazovanja: "Socijalno neosjetljive prakse - primjeri iz hrvatskog visokog obrazovanja«. Zagreb: Institut za razvoj obrazovanja. Preuzeto s: http://www.iro.hr/hr/ javne-politike-visokogobrazovanja/kolumna/socijalno-neosjetljive-prakse. (25.05.2014.).

11. Eggins, H. (2010). Introduction: Access and equity: The issues. Changing inequalities: The necessity for research. In: Eggins, H. (ed.), Access and eEquity. Comparative perspectives. Rotterdami: Sense Publishers, 1-9. 
12. European Universities Charter on Lifelong Learning (2008). Brussels: European University Association.

13. Fajdetić, A., Kiš-Glavaš, L. \& Lisak, N. (2013). Percepcija visokoškolske nastave pristupačne studentima s invaliditetom. Hrvatska revija za rehabilitacijska istraživanja, 49 (2), 28-41.

14. Farnell, N. (2009). Kolumna Javne politike visokog obrazovanja: „Osigurava li besplatno obrazovanje jednak pristup obrazovanju?« Zagreb: Institut za razvoj obrazovanja. Preuzeto s: http://www.h-alter.org/vijesti/politika/ kako-povecati-pristup-visokom-obrazovanju (23.06.2014.).

15. Farnell, T. \& Kovač, V. (2010). Uklanjanje nepravednosti u visokom obrazovanju: prema politici »proširivanja sudjelovanja« u Hrvatskoj. Revija za socijalnu politiku, 17 (2), 257-275.

16. Farnell, T., Doolan, K., Matković, T. \& Cvitan, M. (2011). Socijalna i ekonomska slika studentskog života u Hrvatskoj: Nacionalno izvješće EUROSTUDENT za Hrvatsku. Zagreb: Institut za razvoj obrazovanja.

17. Fejzić, E. (2007). Osobe umjerenih tjelesnih sposobnosti i arhitektonske barijere, Kotor: Ekxpeditio.

18. File J., Farnell T., Doolan K., Lesjak D. \& Šćukanec N. (2013). Financiranje visokog obrazovanja i socijalna dimenzija u Hrvatskoj: analiza i preporuke. Zagreb: Institut za razvoj obrazovanja. Preuzeto s: http://www.tempus-access.info/wp-content/uploads/2013/02/ACCESS_Analize-i-preporuke_web.pdf. (12.06.2014.).

19. Fleischer, A., Adolfsson, M. \& Granlund, M. (2013). Students with disabilities in higher education - perceptions of support needs and received support: A pilot study. International Journal of Rehabilitation Research, 36 (4), 330-338.

20. Franulović, M. (2009). Neki aspekti kvalitete života studenata s invaliditetom (diplomski rad). Zagreb: Studijski centar socijalnog rada, Pravni fakultet Sveučilište u Zagrebu.

21. Greenbank, P. (2007). Higher education and the graduate labour market: The "class factor«. Tertiary Education and Management, 13 (4), 365-376.

22. Ivković, M. (2009). Osiguranje kvalitete u visokom obrazovanju, Ekocentra, 11, 20-23.

23. Izvješće Pravobraniteljice za osobe $\mathbf{s}$ invaliditetom (2012). Preuzeto s: http://www.posi.hr/index.php?limitstart=24 (16.06.2014.).

24. Izvješće Pravobraniteljice za osobe s invaliditetom (2013). Preuzeto s: http. www.posi.hr/index.php?limitstart=24 (16.06.2014.).

25. Key issues for the European higher education area - Social dimension and mobility. Report from the Bologna process working group on social dimension and data on mobility of staff and students in participating countries, Stockholm: Goverment offices of Sweden, Edita. Preuzeto s: ttp:// 
www.ond.vlaanderen.be/hogeronderwijs/bologna/documents/WGR2007/ Socialdimensionandmobilityreport.pdf (13.05.2014.).

26. Konvencija o pravima djeteta (1989). Službeni list SFRJ, 15/1990.

27. Konvencija za zaštitu ljudskih prava i temeljnih sloboda. Narodne novine, 18/1997, 619/99, 14/2002, 13/2003, 9/2005, 1/2006, 2/2010.

28. Konvencija o pravima osoba s invaliditetom (2007.) Narodne novine, $6 / 2007$, $3 / 2008,5 / 2008$

29. Koucký, J., Bartušek, A. \& Kovařovic, J. (2010). Who gets a degree? Access to tertiary education in Europe 1950-2009. Prague: Charles University in Prague, Faculty of Education, Education Policy Centre.

30. Krznarić, S. (2013). Sustav podrške za studente $s$ invaliditetom Sveučilišta u Zagrebu iz perspektive koordinatora. Diplomski rad. Zagreb: Studijski centar socijalnog rada, Pravni fakultet Sveučilišta u Zagrebu.

31. Madriaga, M., Hanson, K., Heaton, C., Kay, H., Newitt, S. \& Walker, A. (2010). Confronting similar challenges? Disabled and nondisabled students'l earning and assessment experiences. Studies in Higher Education, 35 (6), 647-658.

32. Milašin, A., Vranić, T. \& Buljubašić Kuzmanović, V. (2009). Ispitivanje učestalosti verbalne agresije kod djece i mladeži. Život i škola, 22 (2), 116- 141

33. Modernisation of higher education in Europe: Funding and the social dimension (2011). Brussels: Education, Audiovisual and Culture Executive Agency.

34. Nacionalna strategija za izjednačavanje mogućnosti za osobe $s$ invaliditetom 2007.-2015. Narodne novine, 63/2007.

35. Nacionalni program za mlade od 2009. do 2013. godine (2009). Preuzeto s: http://www.hzz.hr/DocSlike/Nacionalni_program_za_mlade_2009-2013.pdf (23.07.2014.).

36. New skills for new jobs: Action now. A report by the Expert Group on new skills for new jobs prepared for the European Commission (2010). Preuzeto s: http://ec.europa.eu/social/main.jsp?catld=568\&langld=en (22.05.2014.)

37. Opća deklaracija o ljudskim pravima (1948). Preuzeto s: http://www.ffzg. unizg.hr/hre-edc/Deklaracijaljp.pdf (24.05.2014.).

38. Osiguravanje minimalnih standarda pristupačnosti visokog obrazovanja za studente $s$ invaliditetom na sveučilištima članicama (2013). Preuzeto s: http://www.unizg.hr/uredssi/images/datoteke/nacionalni_dokument. pdf (15.07.2014.).

39. Pavić, Ž. \& Vukelić, K. (2009). Socijalno podrijetlo i obrazovne nejednakosti: istraživanje na primjeru osječkih studenata i srednjoškolaca. Revija za sociologiju, 40[39] (1-2), 53-70.

40. Plan razvoja sustava odgoja i obrazovanja 2005. - 2010. (2005). Preuzeto s: http://public.mzos.hr/Default.aspx?sec=3135 (24.07.2014.). 
41. Policy guidelines on inclusion in education (2009). Paris: UNESCO.

42. Povelja o temeljnim pravima Europske unije (2009). Preuzeto s: http:// www.mvep.hr/custompages/static/hrv/files/pregovori/111221-lisabonskiprociscena.pdf. (14.05.2014.).

43. Preporuka REC (2006) $\mathbf{5}$ Odbora ministara državama članicama vezana uz Akcijski plan Vijeća Europe za promicanje prava i potpunog sudjelovanja u društvu osoba s invaliditetom: poboljšanje kvalitete života osoba $s$ invaliditetom u Europi 2006. - 2015. (2006). Zagreb: Povjerenstvo Vlade Republike Hrvatske za osobe s invaliditetom, Ministarstvo obitelji, branitelja i međugeneracijske solidarnosti.

44. Puzić, S., Doolan, K. \& Dolenec, D. (2006). Socijalna dimenzija »Bolonjskog procesa«: $(\mathrm{Ne})$ jednakost šansi za visoko obrazovanje: Neka hrvatska iskustava. Sociologija sela, 44, 172-173 (2-3), 243-26.

45. Redmond, P. (2006). Outcasts on the inside: Graduates, employability and widening participation.Tertiary Education and Management, 12 (2), 119135.

46. Rezolucija Vijeća Europe o jednakim mogućnostima obrazovanja i izobrazbe za učenike i studente $s$ invaliditetom (2003). (320030604(01).

47. Rieser, R. (1994). The social model of disability. New Learning Together Magazine, 1, 40-42.

48. Santiago, P., Tremblay, K., Basri, E. \& Arnal, E. (2008). Tertiary education for the knowledge society: Special features: Equity, innovation, labour market, internationalisation. Paris: Organisation for Economic Cooperation and Development.

49. Shevlin, M. \& O'Moore, A. (2000). Creating opportunities for contact between mainstream pupils and their counterparts with learning difficulties. British Journal of Special Education, 27 (1), 29-34.

50. Sinković, G. \& Sinković, E. (2008). Uloga studentske ankete u povećanju kvalitete nastave na visokim učilištima. Ekonomska istraživanja, 21 (2), 34-46.

51. Služba za podršku studentima - analiza opcija (2013). TEMPUS projekt »Jednak pristup za sve - EQUI ED«, Srbija. Preuzeto s: http://www.equied. ni.ac.rs (13.06.2014.).

52. Sporazum o poticajnim mjerama za upis u ustanove visokog obrazovanja (2007). Preuzeto s: https://vlada.gov.hr (28.07.2014.).

53. Strategija Europe 2020. (2010). Preuzeto s: http://www.mobilnost.hr/prilozi/05_1300804774_Europa_2020.pdf (28.07.2014.).

54. Standard rules for equalisation of opportunities for persons with disability (1993). New York: United Nations.

55. Statut Sveučilišta u Rijeci (2008). Preuzeto s: https://www.google.hr/?gws_ $r d=s s l \# q=s t a t u t+s v e u \% C 4 \% 8 D i l i \% C 5 \% A 1 t a+u+r i j e c i(28.07 .2014$.$) .$ 
56. Statut Sveučilišta u Splitu (2009). Preuzeto s: https://www.google.hr/?gws_ $r d=s s \mid \# q=s t a t u t+s v e u \% C 4 \% 8 D i l i \% C 5 \% A 1 t a+u+s p l i t u(28.07 .2014$.$) .$

57. Statut Sveučilišta u Zagrebu. Preuzeto s: http://www.unizg.hr/o-sveucilistu/dokumenti-i-javnost-informacija/propisi/statut-sveucilista-u-zagrebu/ (28.07.2014.).

58. Strateški plan za razdoblje od 2013. - 2015. godine Ministarstva socijalne politike i mladih (2012). Preuzeto s: www.mspm.hr/.../Strateški\%20 plan\%20Ministarstva\%20socijalne\%20pol.(24.06.2014.)

59. Strateški plan Ministarstva znanosti, obrazovanja i sporta 2014-2016. (2013). Preuzeto s: public.mzos.hr/fgs.axd?id=20740 (25.07.2014.)

60. Tempus projekt »EDu Quality - Education for equal opportunities at croatian universities« (2009). Sveučilište u Zagrebu. Preuzeto s: http://www. eduquality-hr.com/ (13.3.2014.).

61. The Bologna process in higher education in Europe. Key indicators on the social dimension and mobility (2009). Luxembourg: EUROSTAT. Preuzeto s: http://www.ond.vlaanderen.be/hogeronderwijs/bologna/conference/ documents/2009_EurostatEurostudent_social_dimension_and_mobility_indicators.pdf (15.3.2014.).

62. The Salamanca statement and framework on special needs education (1994). Paris: UNESCO.

63. Tomaševski, K. (2006). The state of the right to educatin worldwite: Free or fee 2006 global report. Copenhagen: Right to Education Project.

64. Towards the European higher education area: Responding to challenges in a globalised world (2007). Preuzeto s: http://www.ehea.info/Uploads/ Declarations/London_Communique18May2007.pdf (01.07.2014.).

65. Ustav Republike Hrvatske (1990). Narodne novine, 56/1990, 135/1997, 8/1998, 113/2000, 124/2000.

66. Vogel, M. (2004). Editor's note. American Academic, 1 (1), 1-6.

67. World declaration on education for all and framework for action to meet basic learning needs (1990). Paris: UNESCO.

68. World education forum - The Dakar framework for action (2000). Paris: UNESCO.

69. Zajednički memorandum o socijalnom uključivanju Republike Hrvatske (2007). Preuzeto s: http://www.mrms.hr/wp-content/uploads/2012/11/jim. pdf (23.07.2014.).

70. Zakon o potvrđivanju Konvencije o pravima osoba s invaliditetom i Fakultativnog protokola uz Konvenciju o pravima osoba sa invaliditetom (2007). Narodne novine, 6/2007, 3/2008, 5/2009.

71. Zakon o osiguravanju kvalitete u znanosti i visokom obrazovanju (2009). Narodne novine, $45 / 2009$. 
Ljetopis socijalnog rada 2014., 21 (3), 485-509 str.

72. Zakon o socijalnoj skrbi (2013). Narodne novine, 157/2113.

73. Zakon o suzbijanju diskriminacije (2008). Narodne novine, $85 / 2008$.

74. Zakon o znanstvenoj djelatnosti i visokom obrazovanju (2007). Narodne novine, 123/2003, 198/2003, 105/2004, 174/2004, 46/2007.

\section{MREŽNI IZVORI}

http://www.eua.be/pubs/engaging_in_lifelong_learning.pdf (12.05.2014.) 


\title{
Sandra Bošković
}

Iva Rinčić

School of Medicine

University of Rijeka

\section{HIGHER EDUCATION FOR STUDENTS WITH DISABILITIES IN CROATIA}

\author{
SUMMARY
}

The principles of providing equal access to and opportunities for higher education are part of the global initiative to advance the right to education for all, and in the last decades their presence in Croatian public education policies has increased.

This paper presents existing public policies on higher education aimed at students with disabilities, an underrepresented group in the higher education of European Union countries and the Republic of Croatia. Specifically, the paper provides an overview and analysis of the existing legal framework and examines the measures which have been implemented in higher education of students with disabilities. The paper also assesses the quality of higher education for students with disabilities in the Republic of Croatia.

The content analysis of the available documents, policies and measures aimed at increasing the participation of students with disabilities in higher education reveals the current situation, and enables establishing the preconditions necessary for its change. Having in mind that improving the quality of higher education for students with disabilities in Croatia requires systematic effort, the paper concludes with a set of recommendations for the improvement of the current system.

Key words: higher education for all, inclusive approach, students with disabilities, higher education legal framework, Republic of Croatia. 
